\title{
"A CAROLINA", SONETO DE MACHADO DE ASSIS EM MÚSICA DE HOSTÍLIO SOARES
}

\section{MAURO CAMILO DE CHANTAL SANTOS}

Escola de Música da Universidade Federal de Minas Gerais Belo Horizonte, Minas Gerais, Brasil

\section{ARNON SÁVIO REIS DE OLIVEIRA}

Escola de Música da Universidade Federal de Minas Gerais Belo Horizonte, Minas Gerais, Brasil

\section{PATRÍCIA VALADÃO ALMEIDA DE OLIVEIRA}

Escola de Música da Universidade Federal de Minas Gerais Belo Horizonte, Minas Gerais, Brasil

Resumo: Este artigo trata da abordagem do soneto "A Carolina", de Machado de Assis, pelo compositor Hostílio Soares, que o musicou em uma canção para canto e piano. Aspectos composicionais e históricos envolvendo essa composição serão abordados. Serão observados, ainda, apontamentos sobre a relação texto-música presente nessa composição. O objetivo é divulgar parte da obra do compositor mineiro Hostílio Soares, assim como valorizar a obra de Machado de Assis junto à canção de câmara brasileira. Ainda, o presente artigo objetiva proporcionar o entendimento da construção musical dessa canção para um público não versado na linguagem da música.

Palavras-chave: Machado de Assis; poesia; Hostílio Soares; música brasileira; "A Carolina"

\section{"FOR CAROLINA," HOSTÍLIO SOARES'S MUSICAL VERSION OF A SONNET BY MACHADO DE ASSIS}

Abstract: This paper describes composer Hostílio Soares's approach to the sonet "For Carolina" by writer Machado de Assis. The poem was set to music by Soares, who composed a Lied for voice and piano. In order to obtain a better musical understanding of the work, we address its compositional and historical aspects. Furthermore, we will point out the relationship between the text and the music present 
in the piece. This paper seeks to publicize part of the works by the composer from Minas Gerais, Hostílio Soares, and appreciate the importance of Machado de Assis's poetry for Brazilian chamber song. In addition, we intend to facilitate the comprehension of the piece's compositional process for an audience unfamiliar with musical language.

Keywords: Machado de Assis; poetry; Hostílio Soares; Brazilian chamber song; "A Carolina"

\section{Introdução}

$\mathrm{P}$ oucos compositores dedicaram sua pena à obra poética de Machado de Assis (1839-1908) para a canção de câmara brasileira, se compararmos o volume de poemas escritos em relação ao número de composições conhecidas até hoje. Dentre esses compositores, citamos Júlio José Nunes (s.d.), com o "Hino Patriótico", também citado como "Hino dos Voluntários"; Dom José Amat (1810-1875), com a "Cantata da Arcádia", partitura hoje perdida. Ainda, Arthur Napoleão (1843-1925), com a canção "Lua da estiva noite"; Luiza Leonardo (1860-1926), com a valsa "Innocencia"; Alberto Nepomuceno (1864-1920), com "Coração triste"; ${ }^{1}$ Francisco Braga (1868-1945), com "Lágrimas de cera"; Luiz Melgaço (1903-1983), com "Quando ela fala"; e Hostílio Soares (1898-1988), o que mais compôs a partir de poemas de Machado de Assis, perfazendo o total de apenas três canções, a seguir: "Quando ela fala", "Livros e flores" e "A Carolina".

Para o melodrama italiano, Machado traduziu o libreto da ópera Pipelet, ${ }^{2}$ de Wolf-Ferrari (1876-1948), que teve estreia em 24 de novembro de 1859, no Teatro São Pedro de Alcântara, no Rio de Janeiro. No melodrama nacional, a obra de Machado inspirou a composição das óperas Dom Casmurro, de Ronaldo Miranda (1948), e A cartomante, de Jorge Antunes (1942), criada a partir do conto homônimo.

A referência à arte da música está presente em inúmeras criações de Machado. Personagens como Pestana, o pianista do conto "Um homem célebre", ou o personagem principal do conto "O machete", um violoncelista,

\footnotetext{
${ }^{1}$ Esse poema é uma versão em versos para a tradução francesa em prosa, de Judith Gautier (1845-1917), do poema de Su-Tchon, poeta chinês dos séculos X e XI.

2 SCHAPOCHNIK, Edição, recepção e mobilidade do romance Les mystères de Paris no Brasil oitocentista, p. 616.
} 
compõem parte do quadro de personas ligadas à música, criadas pelo escritor. Ainda, o conto "Trio em lá menor", que recebe nomes de movimentos musicais para suas quatro partes (Adagio, Allegro, Allegro apassionatto e Minueto), ou mesmo o tenor Marcolini, em Dom Casmurro, com sua célebre frase: "[...] Deus é o poeta. A música é de Satanás, jovem maestro de muito futuro, que aprendeu no conservatório do céu", se constituem em flertes musicais que Machado demonstrou ao longo de sua produção.

Para o presente artigo, os autores apresentam a canção para canto e piano "A Carolina", do compositor mineiro Hostílio Soares. Aspectos envolvendo o histórico dessa criação serão abordados, bem como a análise de sua composição com ênfase na relação texto-música e, ainda, uma edição de sua partitura. Outrossim, este estudo tem por objetivo a divulgação desse material e a valorização da obra de Machado de Assis na produção musical brasileira, bem como do compositor Hostílio Soares.

\section{1. "A Carolina", soneto de Machado de Assis}

De origem italiana, o soneto é, talvez, dentre todas as poesias líricas de forma fixa, a que apresenta maior vitalidade ao longo dos séculos. Essa forma poética, bem-sucedida em inúmeros idiomas, tem sido objeto de desejo de poetas em língua portuguesa ao longo dos séculos, como Camões (1524-1579 ou 1580), Antero de Quental (1842-1891), Olavo Bilac (1865-1918), Florbela Espanca (1894-1930) e Vinícius de Moraes (1913-1980), entre incontáveis outros.

O soneto "A Carolina" abre o livro Relíquias de casa velha, lançado em 1906, pela editora Garnier, no Rio de Janeiro, e apresenta-se como um soneto petrarquiano, com duas estrofes de quatro versos (quartetos) e duas estrofes de três versos (tercetos). "A Carolina" é reconhecido como o último poema de Machado, tendo sido citado como o "preito de saudade à esposa morta". ${ }^{3}$

A seguir, apresentaremos o soneto "A Carolina", junto à identificação de afetos presentes em seus versos, com o acréscimo de uma possível interpretação de suas paisagens poéticas. Ainda, a conexão desses dados junto ao contexto de vida do poeta Machado de Assis, com sua esposa Carolina, por meio de depoimentos e correspondências disponíveis para consulta:

${ }_{3}^{3}$ PÉREZ, Machado de Assis: esboço biográfico, p. 91. 


\begin{tabular}{|c|c|c|c|}
\hline Estrofes & Versos & $\begin{array}{l}\text { Afetos } \\
\text { presentes no } \\
\text { soneto } \\
\text { "A Carolina" }\end{array}$ & $\begin{array}{l}\text { Contexto de vida } \\
\text { do casal Machado } \\
\text { e Carolina, a } \\
\text { partir de } \\
\text { depoimentos e da } \\
\text { correspondência }\end{array}$ \\
\hline $1^{\mathbf{a}}$ estrofe & $\begin{array}{l}\text { Querida, ao pé do leito derradeiro } \\
\text { Em que descansas dessa longa vida, } \\
\text { Aqui venho e virei, pobre querida, } \\
\text { Trazer-te o coração do companheiro. }\end{array}$ & $\begin{array}{l}\text { Afirmação do } \\
\text { amor do poeta à } \\
\text { esposa, junto a seu } \\
\text { túmulo, e a } \\
\text { promessa de } \\
\text { sempre visitá-lo. }\end{array}$ & $\begin{array}{l}\text { O casal Machado e } \\
\text { Carolina viveu por } \\
\text { quase } 35 \text { anos em } \\
\text { uma relação } \\
\text { notoriamente } \\
\text { reconhecida como } \\
\text { feliz. Em entrevista } \\
\text { para o jornal } O \text { Globo, } \\
\text { em 2008, a sobrinha- } \\
\text { bisneta de Carolina, } \\
\text { Ruth Leitão de } \\
\text { Carvalho Lima, } \\
\text { afirmou que após a } \\
\text { morte de Carolina: } \\
\text { "Ele deixou tudo } \\
\text { como era em casa. E } \\
\text { sempre almoçava e } \\
\text { jantava com dois } \\
\text { pratos à mesa". }\end{array}$ \\
\hline $2^{\mathbf{a}}$ estrofe & $\begin{array}{l}\text { Pulsa-lhe aquele afeto verdadeiro } \\
\text { Que, a despeito de toda a humana lida, } \\
\text { Fez a nossa existência apetecida } \\
\text { E num recanto pôs um mundo inteiro. }\end{array}$ & $\begin{array}{l}\text { Afirmação do } \\
\text { amor de ambos, } \\
\text { apesar das } \\
\text { dificuldades da } \\
\text { vida, numa relação } \\
\text { "apetecida". }\end{array}$ & $\begin{array}{l}\text { Parte da } \\
\text { correspondência } \\
\text { entre o poeta e } \\
\text { Carolina nos mostra } \\
\text { os valores que } \\
\text { alicerçavam a relação } \\
\text { do casal: "Depois... } \\
\text { depois, querida, } \\
\text { ganharemos o } \\
\text { mundo, porque só é } \\
\text { verdadeiramente } \\
\text { senhor do mundo } \\
\text { quem está acima das } \\
\text { suas glórias fofas e } \\
\text { das suas ambições } \\
\text { estéreis. Estamos } \\
\text { ambos neste caso; } \\
\text { amamo-nos; e eu vivo } \\
\text { e morro por ti. } \\
\text { Escreve-me e crê no } \\
\text { coração do teu } \\
\text { Machadinho". }\end{array}$ \\
\hline $3^{\mathbf{a}}$ estrofe & Trago-te flores - restos arrancados & O ritual de levar & O ritual de afeto ao \\
\hline
\end{tabular}




\begin{tabular}{|c|c|c|c|}
\hline & $\begin{array}{l}\text { Da terra que nos viu passar unidos } \\
\text { E ora mortos nos deixa e separados. }\end{array}$ & $\begin{array}{l}\text { flores, "restos } \\
\text { arrancados", como } \\
\text { uma das poucas } \\
\text { maneiras possíveis } \\
\text { ao poeta para } \\
\text { demonstrar seu } \\
\text { amor e sua } \\
\text { saudade. }\end{array}$ & $\begin{array}{l}\text { oferecer flores pode } \\
\text { ser notado durante o } \\
\text { período de } \\
\text { convivência do casal. } \\
\text { Uma carta de } \\
\text { Machado endereçada } \\
\text { a Carolina, datada de } \\
2 \text { de março, sem } \\
\text { registro do ano, nos } \\
\text { mostra o carinho do } \\
\text { poeta para com sua } \\
\text { esposa: "Obrigado } \\
\text { pela flor que me } \\
\text { mandaste; dei-lhe } \\
\text { dois beijos como se } \\
\text { fosse em ti mesma, } \\
\text { pois que apesar de } \\
\text { seca e sem perfume, } \\
\text { trouxe-me ela um } \\
\text { pouco de tua alma". }\end{array}$ \\
\hline $4^{\mathbf{a}}$ estrofe & $\begin{array}{l}\text { Que eu, se tenho nos olhos mal feridos } \\
\text { Pensamentos de vida formulados, } \\
\text { São pensamentos idos e vividos. }\end{array}$ & $\begin{array}{l}\text { Em sua tristeza, o } \\
\text { poeta se declara } \\
\text { morto para sua } \\
\text { realidade, assim } \\
\text { como Carolina. } \\
\text { Questiona que, se } \\
\text { ainda possui } \\
\text { pensamentos, eles } \\
\text { são, todos, para } \\
\text { momentos do } \\
\text { passado. }\end{array}$ & $\begin{array}{l}\text { Em carta endereçada } \\
\text { a Joaquim Nabuco, } \\
\text { datada de } 20 \text { de } \\
\text { novembro de } 1904 \text {, } \\
\text { Machado declara: } \\
\text { "Foi-se a melhor } \\
\text { parte da minha vida, } \\
\text { e aqui estou só no } \\
\text { mundo". Na mesma } \\
\text { carta, mais adiante, } \\
\text { resume sua condição } \\
\text { à época: "Tudo me } \\
\text { lembra a minha } \\
\text { meiga Carolina. } \\
\text { Como estou à beira } \\
\text { do eterno aposento, } \\
\text { não gastarei muito } \\
\text { tempo em recordá-la. } \\
\text { Irei vê-la, ela me } \\
\text { esperará". }\end{array}$ \\
\hline
\end{tabular}

Quadro 1: Interpretação do soneto "A Carolina", indicação de afetos e aspectos biográficos da história de Machado e sua esposa Carolina Augusta, ligados ao texto poético

Ao percebermos o cenário que envolveu a criação desse soneto, podemos supor o quanto sua gênese significou para o homem por trás do poeta. 


\section{Carolina Augusta Xavier de Novais, esposa de Machado de Assis}

Filha de um ourives, Carolina Augusta Xavier de Novais era portuguesa, tendo nascido na cidade do Porto, no ano de 1835. O ano de 1866 marca a chegada de Carolina ao Brasil. Há diversas especulações sobre a vinda de Carolina Augusta ao Brasil. Entre elas, a de que teria aportado no país após alguma desilusão amorosa. O que se pode afirmar, com certeza, é que seu irmão, o poeta Faustino Xavier de Novais (1820-1869), já se encontrava no Rio de Janeiro quando da chegada de Carolina. Referido sempre como amigo de Machado de Assis, Faustino Xavier de Novais talvez tenha proporcionado o primeiro encontro entre Carolina e Machado, que resultaria na união de ambos. O casamento de Carolina Augusta e Machado, união que durou quase 35 anos, se deu a 12 de novembro de 1869 . O casal não teve filhos.

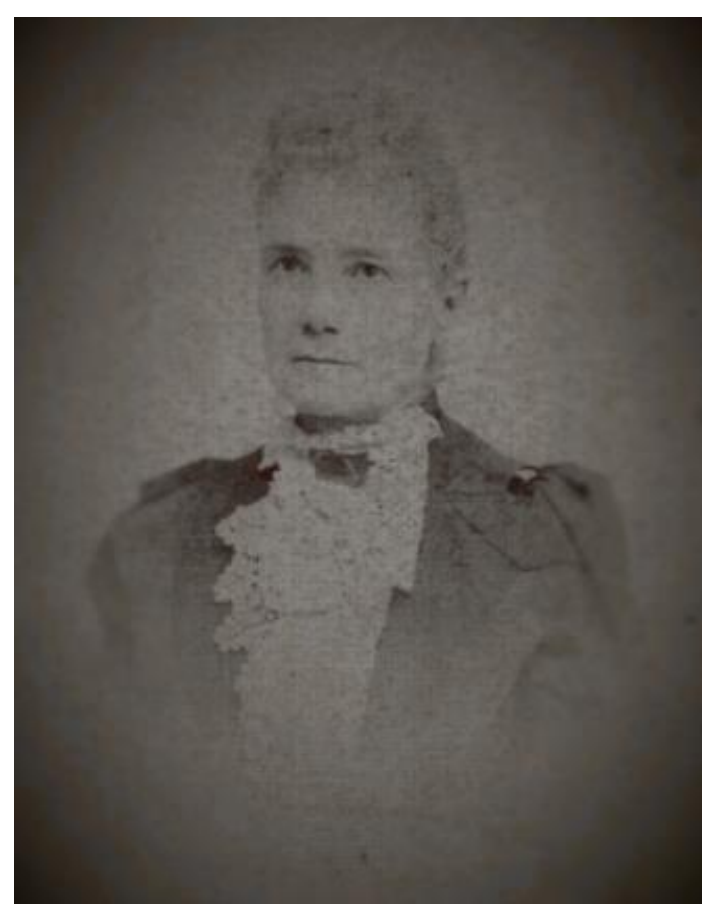

Fig. 1: Uma das raras fotos de Carolina

Augusta, sem data

Carolina Augusta faleceu no dia 20 de outubro de 1904. Em diversos jornais da época, sua morte foi divulgada pela imprensa carioca, que sempre a citou como esposa de Machado de Assis. Para a realização deste artigo, resgatamos uma nota sobre seu falecimento, lançada pelo jornal $O$ Fluminense, no dia 22 de outubro de 1904: 


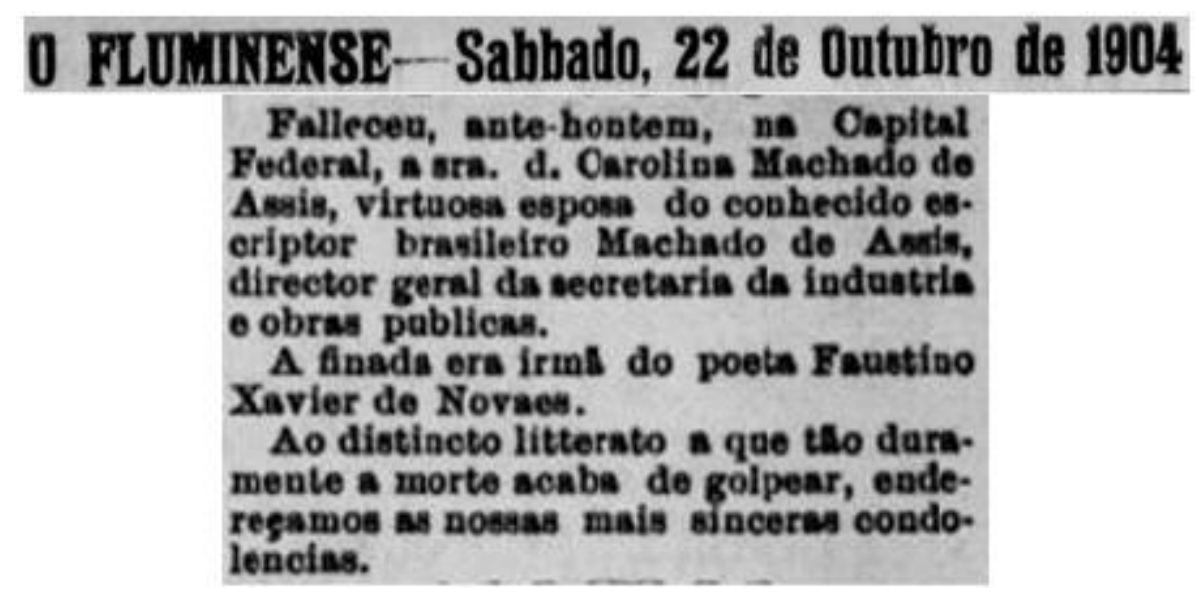

Fig. 2: Nota do jornal O Fluminense sobre o falecimento de Carolina Augusta

Dentre diversas manifestações de consolo dirigidas a Machado, pelo falecimento de Carolina, são tocantes as palavras enviadas e recebidas por Joaquim Nabuco (1849-1910). A carta de Joaquim Nabuco fora escrita em Londres, no dia 17 de novembro de 1904. Nela, Nabuco escreve:

Meu caro Machado,

Que lhe hei de dizer? Morrer antes de V. foi um ato de misericórdia que a Providência dispensou a Dona Carolina. A viúva sofre sempre mais, às vezes tragicamente. No seu caso, a imaginação, o interesse intelectual, o trabalho é um ambiente que permite em parte à dor a evaporação excessiva. A solução do dilema inevitável foi a melhor para ambos: coube a V. o sofrimento, V. compreenderá que o vácuo do coração precisa ser compensado pelo movimento e pela agitação do seu espírito. Será este o seu conforto e a maior dívida da nossa língua para com o túmulo a cuja sombra V. vai se acolher. [...]

O impacto da morte da esposa de Machado pôde ser sentido na resposta que o escritor enviou a seu amigo Nabuco, um mês após o falecimento de Carolina. A carta foi escrita na cidade do Rio de Janeiro, no dia 20 de novembro de 1904, e contém a seguinte mensagem:

Tão longe, em outro meio, chegou-lhe a notícia da minha grande desgraça, e você expressou logo a sua simpatia por um telegrama. A única palavra com que lhe agradeci é a mesma que ora lhe mando, não sabendo outra que possa dizer tudo o que sinto e me acabrunha. Foi-se a melhor parte da minha vida, e aqui estou só no mundo. Note que a solidão não me é enfadonha, antes me é grata, porque é um modo de viver com ela, ouvi-la, assistir aos mil cuidados que essa companheira 
de 35 anos de casados tinha comigo; mas não há imaginação que não acorde, e a vigília aumenta a falta da pessoa amada. Éramos velhos, e eu contava morrer antes dela, o que seria um grande favor; primeiro porque não acharia a ninguém que melhor me ajudasse a morrer; segundo, porque ela deixa alguns parentes que a consolariam das saudades, e eu não tenho nenhum. Os meus são os amigos, e verdadeiramente são os melhores; mas a vida os dispersa, no espaço, nas preocupações do espírito e na própria carreira que a cada um cabe. Aqui me fico, por ora na mesma casa, no mesmo aposento, com os mesmos adornos seus. Tudo me lembra a minha meiga Carolina. Como estou à beira do eterno aposento, não gastarei muito tempo em recordá-la. Irei vê-la, ela me esperará.

Não posso, meu caro amigo, responder agora à sua carta de 8 de outubro; recebi-a dias depois do falecimento de minha mulher, e você compreende que apenas posso falar deste fundo golpe.

Até outra e breve; então lhe direi o que convém ao assunto daquela carta, que, pelo afeto e sinceridade, chegou à hora dos melhores remédios. Aceite este abraço do triste amigo velho

Machado de Assis

Quase quatro anos completos viveu Machado de Assis, após a perda de sua esposa Carolina. Deprimido e tendo agravado seus problemas de saúde com a epilepsia, o poeta escreveu, como fruto de seus sentimentos pela morte da esposa, o soneto "A Carolina", que permanece na poesia nacional como símbolo da união de ambos. Machado de Assis foi sepultado em 1908, segundo sua vontade, na sepultura de Carolina, no Cemitério de São João Batista. Passados noventa anos, no dia 21 de abril de 1999, os restos mortais de Machado e de sua esposa Carolina foram trasladados para o Mausoléu da Academia, que também se encontra no Cemitério São João Batista, na cidade do Rio de Janeiro.

\section{Hostílio Soares, compositor da canção para canto e piano "A Carolina"}

O compositor Hostílio Soares nasceu em Visconde do Rio Branco, Minas Gerais, e faleceu em Belo Horizonte. Estudou com importantes professores brasileiros, no Instituto Nacional de Música, na então capital do Brasil, a cidade do Rio de Janeiro. Sua formação em Harmonia, Contraponto e Fuga se deu pelas mãos de José Paulo Silva (1892-1967). Com Francisco 
Braga, que foi discípulo de Jules Massenet (1842-1912), Hostílio Soares estudou Composição e Instrumentação.

Transferindo-se para a capital mineira em 1931, assumiu o posto de professor do Conservatório Mineiro de Música no ano seguinte, lecionando Contraponto e Fuga. Nessa instituição, que se transformaria na atual Escola de Música da UFMG, o compositor lecionou por 34 anos, designado para as cadeiras de Harmonia Elementar e Superior, Composição e Instrumentação.

Hostílio Soares viveu cinquenta e seis anos em Belo Horizonte, com intensa produção musical nas décadas de 1940, 1950 e 1960. Compôs óperas, sinfonias, missas, música para coro a capela e com acompanhamento, canções de câmara e para outras formações musicais. Como regente, dirigiu a estreia mundial da ópera $O$ sertão, do francês Fernando Jouteux (1866-1956), em Belo Horizonte, em 1954. Autor de vasta obra musical, foi definido como um compositor do que em música é chamado de romantismo tardio, ou alto romantismo, "no qual a expressividade é valorizada ao extremo, utilizando o cromatismo como principal elemento de estruturação de uma composição, mas sem se desvencilhar, contudo, dos princípios tonais e formais do século XIX". ${ }^{4}$

Além da atividade como docente e compositor, Hostílio Soares teve publicado o livro Miniaturas e aquarelas. Esse pequeno livro de sonetos contém "poemas românticos, simbolistas, parnasianos e modernos". ${ }^{5}$ Hostílio Soares escreveu e defendeu, ainda, a tese Técnica de canto coral e o estudo de solfejo, apresentada ao concurso para catedrático de Teoria Musical, da Escola Nacional do Rio de Janeiro.

Com a aposentadoria, Hostílio Soares dedicou-se à restauração e revisão de suas composições, retirando-se do cenário musical de Belo Horizonte. Em seus últimos anos, participou ativamente da Sociedade Teosófica. ${ }^{6}$ Faleceu em sua cidade natal, em 1988, aos noventa anos de idade. Desde a década de 1990, sua obra tem despertado a atenção de pesquisadores e intérpretes, e, por meio da pesquisa acadêmica, encontra, aos poucos, seu espaço junto à história da música brasileira.

${ }^{4}$ OLIVEIRA, O coro do Brasil: o madrigal renascentista e o contexto de seu percurso (1956-1962), p. 44.

5 TEIXEIRA, As canções de Hostílio Soares: Álbum para canto e piano: cinco peças em vernáculo, p. 24.

${ }^{6}$ OLIVEIRA, Hostílio Soares: As sete palavras de Christus Cruxificatum - Edição crítica, p. 30. 
4. A canção para canto e piano "A Carolina", de Hostílio Soares, a partir do poema de Machado de Assis

A canção "A Carolina" está inserida no Álbum para canto e piano - cinco peças em vernáculo, obra com a qual o compositor venceu o concurso para compositores residentes em Minas Gerais, em 1963, promovido pela Secretaria de Cultura de Minas Gerais. Esse álbum apresenta as seguintes canções: "Livros e flores", com poesia de Machado de Assis; "Quando ela fala", com poesia de Machado de Assis; "A Carolina", soneto de Machado de Assis; "Sinos", soneto de Carmen Melo, e "As duas sombras", com poesia de Olegário Mariano (1889-1958).

Composta na tonalidade de Fá maior, com a indicação de andamento Adagio, ou seja, para ser tocada lentamente, comodamente. Essa canção permanece até hoje manuscrita. As dinâmicas utilizadas pelo compositor, tanto para a linha vocal quanto para o acompanhamento pelo piano, são: $p \boldsymbol{p}$ (pianíssimo), $p$ (piano), cres. (crescendo), $f$ (forte) e dim. (diminuendo). No primeiro compasso da escrita para o piano, há a indicação de uma articulação em legato (ligado), que exige do intérprete a execução de notas sucessivas, sem que nenhum silêncio ocorra entre elas, a menos que haja a indicação de pausas musicais.

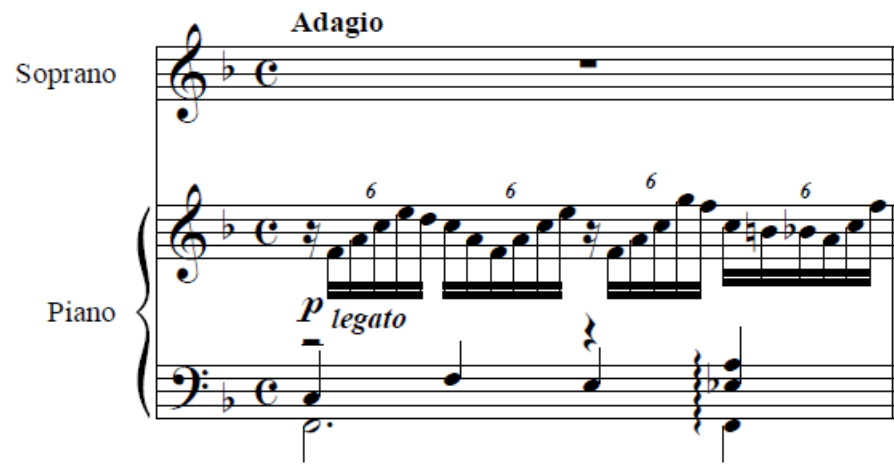

Fig. 3: A indicação de legato para a escrita do piano na canção "A Carolina"

Digno de nota é observarmos a presença de uma célula rítmica contendo doze valores musicais iguais, sendo onze deles em semicolcheias, e um em pausa de semicolcheia. Essa célula rítmica foi escrita para a mão direita ao piano, e se mantém a mesma desde o compasso 1 até o compasso 35. Essa escrita é sugestiva para o suspiro: a angústia por não possuir o apoio no primeiro tempo do compasso, sendo ele realizado pontualmente pela mão esquerda, com uma sonoridade mais grave e solene, indicando, talvez, que o 
apoio de que o poeta necessita se encontra em outro plano que não aquele em que se encontra. Essa constância rítmica presente na escrita para a mão direita ao piano pode, ainda, sugerir a constância do sentimento do poeta durante seu discurso nesse soneto.

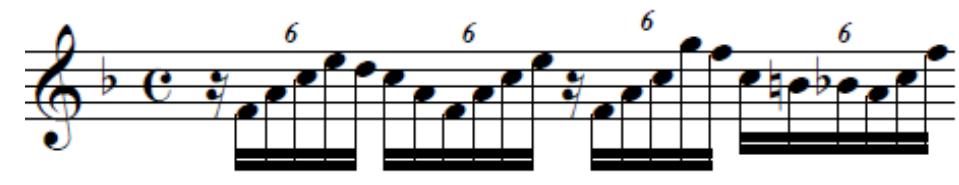

Fig. 4: Estrutura rítmica utilizada pelo compositor Hostílio Soares em quase toda a canção "A Carolina", com indicação sugestiva para a ilustração de afetos que permeiam o eu lírico do poema

Por sua extensão vocal, que abrange as notas Dó 3 ao Fá 4, e escrita na clave de sol, chegamos à conclusão de que o compositor pensou em uma voz aguda para sua performance. Nesse sentido, primeiramente, indicamos a voz de tenor, a mais aguda voz masculina, como apta para a realização da partitura. Isso se dá pelo eu lírico do poema ser masculino. No entanto, é comum na realização da canção de câmara brasileira, bem como na música popular, vozes femininas executarem textos cujo eu lírico é masculino. Assim, a canção "A Carolina" pode ser cantada por uma voz de soprano ou mezzo-soprano. Ao todo, a canção possui trinta e oito compassos.

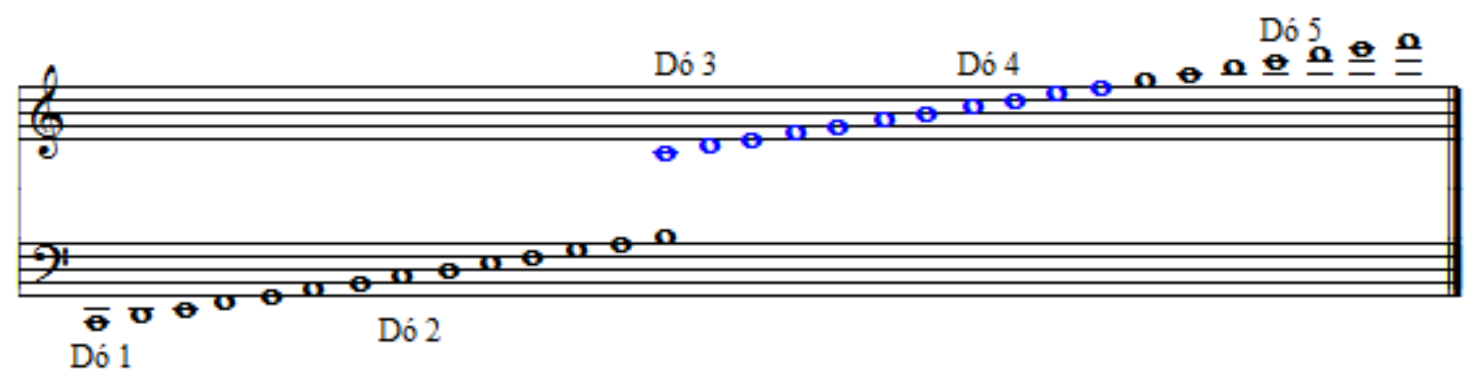

Fig. 5: Sistema de designação de alturas. Extensão vocal da canção "A Carolina", indicada em azul, abrangendo as notas Dó 3 ao Fá 4

É possível apontarmos um dialogismo entre a tonalidade escolhida por Hostílio Soares para compor a canção "A Carolina" e a Teoria dos Afetos ${ }^{7}$ estudada por Johann Mattheson (1681-1764), em sua obra Der Vollkommene Capellmeister, de 1739. Para Mattheson, os afetos estavam ligados às

\footnotetext{
7 A Teoria dos Afetos, também chamada de Doutrina dos Afetos, propunha recursos técnicos de composição para despertar emoções específicas nos ouvintes. Embora tenha sua gênese na Antiguidade, seu apogeu ocorreu no período barroco.
} 
tonalidades musicais de forma objetiva, coerente, como nos mostra o quadro a seguir:

\begin{tabular}{|c|c|c|c|}
\hline Tonalidades & Afetos & Tonalidades & Afetos \\
\hline Ré menor & $\begin{array}{l}\text { Devoto, calmo, } \\
\text { fluente grandioso }\end{array}$ & Sol maior & Insinuante, falante \\
\hline Sol menor & $\begin{array}{l}\text { Serenidade, } \\
\text { amabilidade, } \\
\text { vivacidade }\end{array}$ & Dó menor & Amável e triste \\
\hline Lá menor & $\begin{array}{l}\text { Lamentosa, } \\
\text { respeitável e serena }\end{array}$ & Fá menor & $\begin{array}{l}\text { Suave, serena, } \\
\text { profunda e pesada }\end{array}$ \\
\hline Mi menor & $\begin{array}{l}\text { Pensamentos } \\
\text { pesados, aflitos e } \\
\text { tristes }\end{array}$ & Si bemol maior & $\begin{array}{l}\text { Divertido e } \\
\text { exuberante }\end{array}$ \\
\hline Dó maior & Rude e atrevido & Mi bemol maior & Patético \\
\hline Fá maior & $\begin{array}{l}\text { É capaz de exprimir } \\
\text { os mais belos } \\
\text { sentimentos do } \\
\text { mundo }\end{array}$ & La maior & $\begin{array}{l}\text { Paixões lamentosas } \\
\text { tristes }\end{array}$ \\
\hline Ré maior & Penetrante e teimosa & Mi maior & Desespero \\
\hline Si menor & Bizarro, melancólico & Fá sustenido menor & Tristeza, aflição \\
\hline
\end{tabular}

Quadro 2: Afetos ligados a tonalidades específicas no livro Der Vollkommene Capellmeister, de 1739, escrito por Johan Mattheson

No caso específico da canção "A Carolina", a tonalidade de Fá maior, se observarmos a relação proposta na Teoria dos Afetos observada por Mattheson, é utilizada para "exprimir os mais belos sentimentos do mundo". Por experiência, ao analisarmos outras obras do compositor mineiro, o uso das tonalidades, referindo-se a caracteres específicos dessa teoria, ultrapassa o significado de coincidência.

Para uma movimentação musical que pode ilustrar a inquietação do poeta ao vivenciar a morte da esposa, Hostílio Soares valeu-se da escrita musical para a mão direita do piano por meio do uso de quiálteras. ${ }^{8}$ Essa movimentação rítmica está presente em toda a canção, com exceção dos dois últimos compassos, 37 e 38, que apresentam um desacelerando rítmico progressivo, por meio de valores rítmicos cada vez maiores.

${ }^{8}$ Quiálteras são possibilidades para dividirmos notas musicais em proporções diferentes daquelas estabelecidas pela subdivisão usual de valores. 


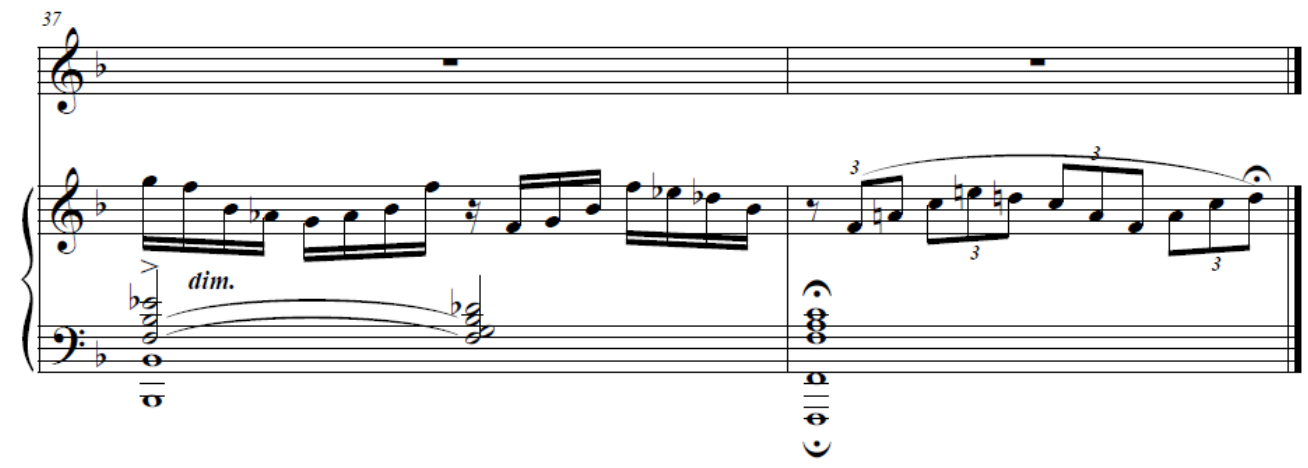

Fig. 6: Os compassos 37 e 38, os últimos da canção "A Carolina", são os únicos que apresentam variações rítmicas na escrita para a mão direita do piano

No aspecto melódico, como traço marcante do compositor, apontamos a presença de cromatismos, tanto na linha vocal quanto instrumental. $\mathrm{Na}$ canção "A Carolina", toda a linha vocal é expressa em ritmos regulares, sem alterações sensíveis da declamação do texto. Podemos afirmar que a escrita vocal nessa canção visa à declamação do texto poético, com a presença massiva de graus conjuntos em sua construção.9 Essa regularidade, confrontada com o ritmo em quiálteras, escrito para a mão direita do piano, cria um ambiente de tensão interna, talvez com a intenção de ilustrar o sentimento pensado pelo compositor. Em relação aos aspectos estruturais, a canção "A Carolina" se divide em quatro seções, sendo que cada seção corresponde a uma estrofe do poema, como nos mostra o quadro a seguir:

\begin{tabular}{|c|c|c|c|}
\hline Estrofes & Versos & $\begin{array}{l}\text { Seções musicais na } \\
\text { canção "A } \\
\text { Carolina" }\end{array}$ & Compassos \\
\hline $1^{\mathbf{a}}$ estrofe & $\begin{array}{l}\text { Querida, ao pé do leito derradeiro } \\
\text { Em que descansas dessa longa vida, } \\
\text { Aqui venho e virei, pobre querida, } \\
\text { Trazer-te o coração do companheiro. }\end{array}$ & Primeira seção & 1 a 12 \\
\hline $2^{\mathbf{a}}$ estrofe & $\begin{array}{l}\text { Pulsa-lhe aquele afeto verdadeiro } \\
\text { Que, a despeito de toda a humana lida, } \\
\text { Fez a nossa existência apetecida } \\
\text { E num recanto pôs um mundo inteiro. }\end{array}$ & Segunda seção & 13 a 22 \\
\hline $3^{\mathbf{a}}$ estrofe & $\begin{array}{l}\text { Trago-te flores - restos arrancados } \\
\text { Da terra que nos viu passar unidos } \\
\text { ora mortos nos deixa e separados. }\end{array}$ & Terceira seção & 23 a 29 \\
\hline
\end{tabular}

9 Graus conjuntos se caracterizam por notas próximas umas às outras, com intervalos que se assemelham à fala comum, nesse caso, para a linha vocal. 


\begin{tabular}{|l|l|c|c|}
\hline $4^{\mathbf{a}}$ estrofe & $\begin{array}{l}\text { Que eu, se tenho nos olhos mal feridos } \\
\text { Pensamentos de vida formulados, São } \\
\text { pensamentos idos e vividos. }\end{array}$ & Quarta seção & 30 a 38 \\
\hline
\end{tabular}

Quadro 3: Seções musicais na canção "A Carolina", divididas na partitura musical de acordo com a estrutura do soneto homônimo

Sobre a relação texto-música contida nessa canção, observamos, já nos dois primeiros compassos, o movimento descendente em notas graves do piano, na escrita para a clave de Fá, o que mostra a intenção do compositor em criar um ambiente musical que reflita o estado de espírito do poeta ao pensar o texto. Em música, o movimento sonoro descendente, sobretudo em notas muito próximas, é conhecido como catabasis. Essa movimentação pode ilustrar uma gama de afetos próximos à tristeza, bem como favorecer a sensação de intimidade, interiorização, tensão e prostração. Além disso, o ritmo constante da mão direita, pensada melodicamente sempre em arpejos, em oposição aos ritmos regulares da linha vocal, cria uma polirritmia que nos remete a uma atmosfera tensa e conturbada. Cabe ressaltar que notas graves de sustentação são utilizadas ao longo de toda a peça, como uma referência a um pulsar rítmico usualmente utilizado em marchas fúnebres.

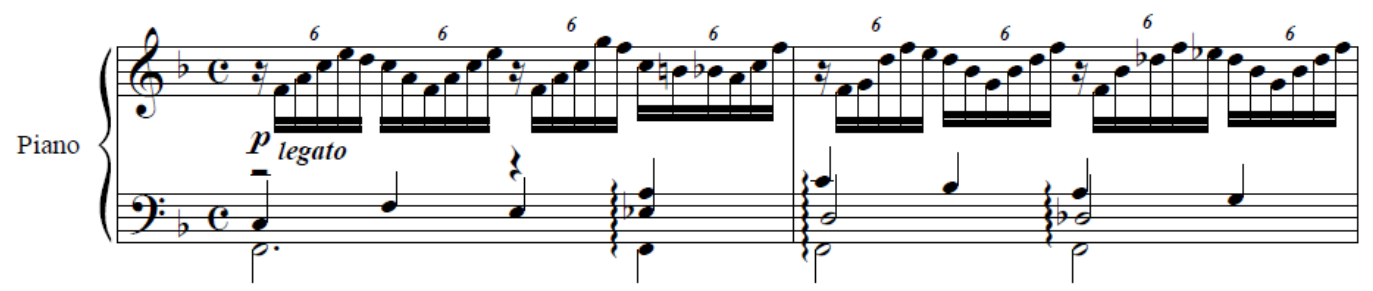

Fig. 7: A presença de catabasis na escrita para a mão esquerda, já nos dois primeiros compassos da canção "A Carolina", como elemento significativo de relação texto-música na obra de Hostílio Soares

Do compasso 1 ao 12, em que é apresentada a primeira seção musical, apontamos a presença de frases melódicas descendentes. O clímax dessa seção, coincidente com a entrega do coração à amada, é seguido de um movimento rápido descendente que conduz a uma nova tônica, Ré menor, relativo obscuro do tom inicial, Fá maior. 

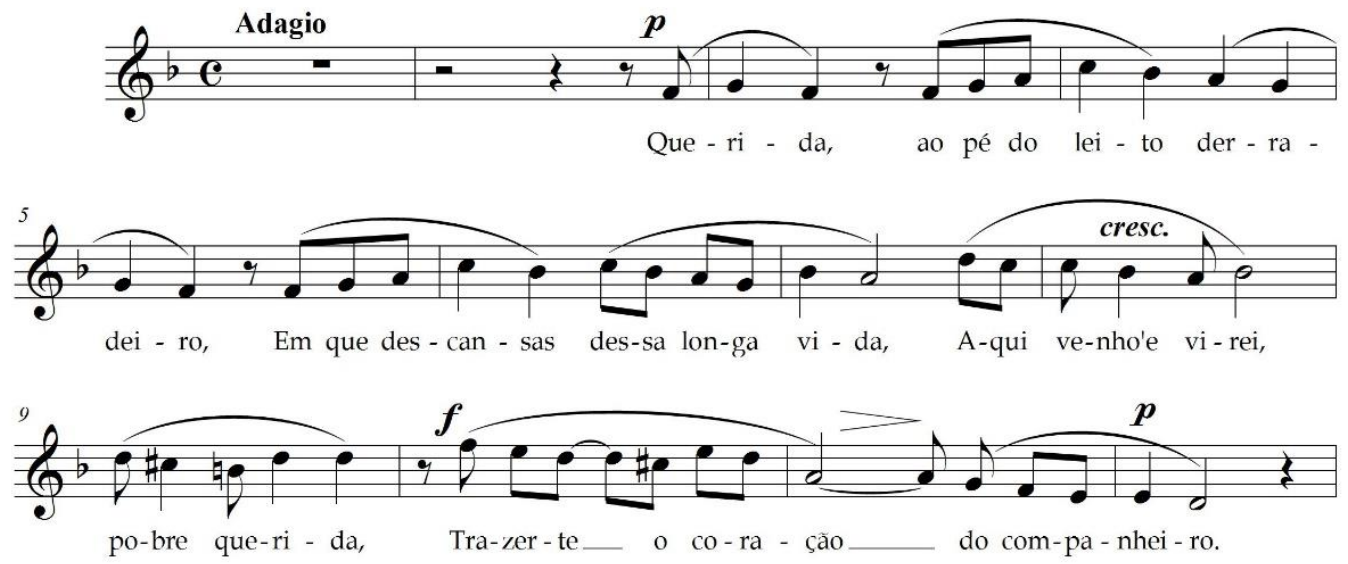

Fig. 8: Frases iniciais da canção "A Carolina", compassos 1 ao 12, com a presença de frases com movimentação descendente (catabasis)

Essa mesma disposição para finalização de frases melódicas com movimento descendente, indicada anteriormente, será ainda usada pelo compositor nas três seções seguintes, até o final da composição.

Digna de nota é a ilustração que ocorre no compasso 27 , na terceira seção musical da canção, com parte da palavra "unidos", em que ele utiliza duas notas contornando uma terceira, sem dúvida uma sutileza musical para antes de atingir a nota única desejada, como duas pessoas separadas que se unem em uma nota final.

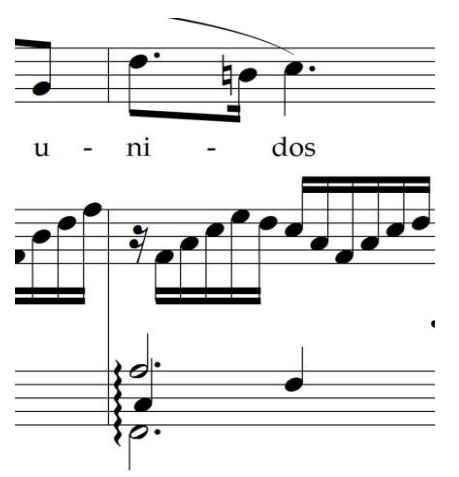

Fig. 9: Uma das sutilezas apresentadas por Hostílio Soares na canção "A Carolina", com a ilustração em música da palavra "unidos"

Igualmente é sugestiva a sequência final da composição, do compasso 30 ao 38 , que também termina harmonicamente suspensa no compasso 38, numa alusão clara a uma possibilidade de continuidade existencial. Aqui, interessa um conhecimento sobre a visão espiritual de Hostílio Soares, que era teosofista, e que, de maneira particular, sugere que essa separação seria temporária. 
No compasso 30, toda a tristeza se proteja na utilização do tom homônimo da tonalidade original, Fá maior, para a tonalidade de Fá menor. Em música, muitas vezes a alteração de uma tonalidade maior para outra menor sugere uma oposição entre alegria e tristeza, o que não acontece nessa peça, visto que o afeto de tristeza domina toda a composição. Essa alteração entre tonalidades pode ilustrar, ainda, mudanças na expressividade do texto musical, de forma a produzir um efeito tido como mais intimista, se associarmos o que Mattheson nos mostra sobre a tonalidade de Fá menor, classificando-a como "suave, serena, profunda e pesada".

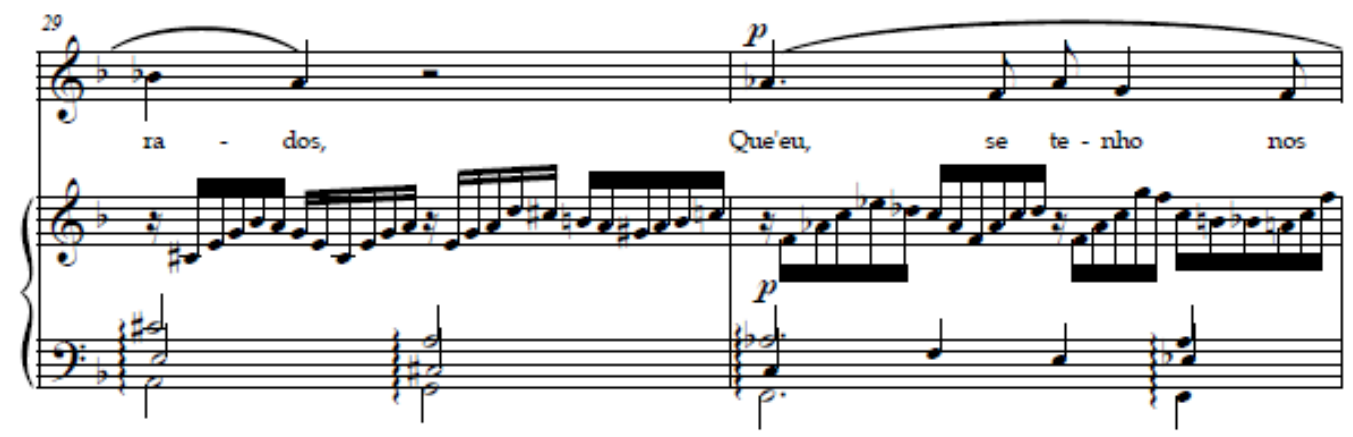

Fig. 10: A mudança de tonalidade maior para menor, entre os compassos 29 e 30, sugestiva de que além da tristeza exposta desde o início do soneto há, ainda, uma nova consciência de resignação em relação ao luto inevitável

Posteriormente, nos compassos 35 e 36, apontamos essa modificação sutil proposta pelo compositor, quando ilustra as palavras "idos e vividos", ainda na tonalidade de Fá menor, na quarta e última estrofe do soneto, como pensamentos íntimos que restaram ao eu lírico, viúvo, triste e resignado em sua sorte, sendo essa tonalidade menor o ambiente perfeito para a ilustração dos últimos pensamentos do poeta no soneto "A Carolina".

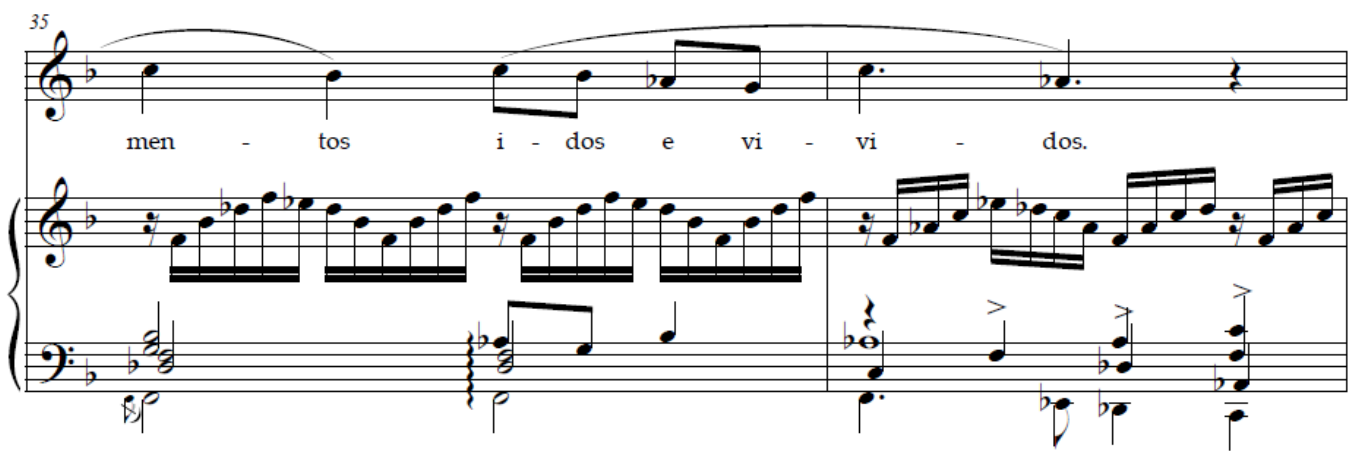

Fig. 11: A utilização da tonalidade de Fá menor pelo compositor Hostílio Soares, para a ilustração das últimas palavras do último soneto escrito por Machado de Assis 
Como citado anteriormente, a canção nos mostra um enfraquecimento dos valores musicais usados nos compassos 37 e 38, na escrita para a mão direita, no acompanhamento do piano. Esse enfraquecimento apresenta como resultado sonoro uma desaceleração da frase musical. Em termos musicais, trata-se de um ritardando, que significa desacelerando, efeito sonoro que dá a impressão de que a música está parando aos poucos, com ou sem perda de sua sonoridade. Ao pensarmos em uma relação texto-música, a escrita para o piano nos três últimos compassos da canção "A Carolina" pode sugerir, na visão do compositor, a perda de forças, a resignação do poeta após ter exposto sua dor e suas intenções futuras para com a memória de Carolina. Salientamos a última nota escrita para essa canção, que não é uma nota comum ao acorde da tonalidade da peça, mas sim o sexto grau (nota Ré 4). Hostílio Soares tinha uma predileção estilística pelo encerramento de peças com um acorde com sexta acrescentada. Essa escrita, presente em diversas composições suas, era uma espécie de assinatura musical. No caso específico da canção "A Carolina", como a última nota não nos permite a sensação de repouso final proporcionado pelo acorde de tônica, a presença dessa nota incomum nos dá a sensação de continuidade do sofrimento do poeta. Ainda, a presença de uma fermata ${ }^{10}$ na última nota da canção permite que o último som da mesma seja prolongado por vontade própria do intérprete. Ora, se pensarmos na linha vocal como a própria voz do poeta, e na linha instrumental do piano como sua periferia, podemos supor que seu sofrimento o acompanhará ainda, por um tempo maior que sua própria capacidade de vivenciar e entender os fatos pelos quais passou.

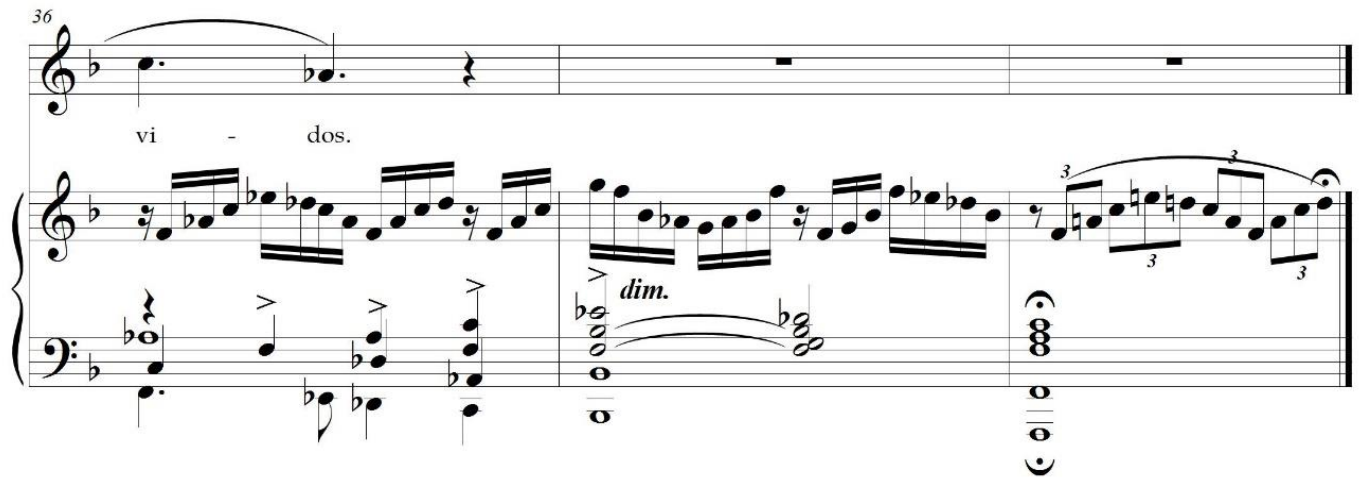

Fig. 12: A mudança de valores rítmicos nos dois últimos compassos da canção, com possível ideia de reticências, por parte do compositor, em relação ao sentido do texto poético projetado no futuro do eu lírico

10 Símbolo de fermata $(\curvearrowright$ ) indica que devemos sustentá-la em aproximadamente $1 / 2$ do valor da figura musical que a antecede. No entanto, na maioria das vezes, essa duração é decidida pelo próprio intérprete, como demonstração de sua própria musicalidade. 
Ao final deste estudo, esperam os autores terem contribuído para a divulgação de uma das poucas canções brasileiras para canto e piano compostas a partir da poesia de Machado de Assis. Digna de estudo e apreciação, a canção "A Carolina", de Hostílio Soares, permanece até hoje como a única abordagem desse gênero sobre o soneto homônimo de Machado.

\section{Referências}

\section{Livros}

ASSIS, Machado de. A poesia completa. Org. Rutzkaya Q. dos Reis. São Paulo: Nankin; Edusp, 2009. Obra completa, vol. II. Rio de Janeiro: Nova Aguilar, 1994. CORRESPONDÊNCIA Machado de Assis $\mathcal{E}$ Joaquim Nabuco. Organização de Graça Aranha. Rio de Janeiro: Academia Brasileira de Letras/Topbooks, 2003.

HARNONCOURT, Nikolaus. O diálogo musical: Monteverdi, Bach e Mozart. Trad. Luís Paulo Sampaio. Rio de Janeiro: Ed. Jorge Zahar, 1993.

. O discurso dos sons. Trad. Luís Paulo Sampaio. Rio de Janeiro: Ed. Jorge Zahar, 1998.

HARRISS, Ernest Charles: Johann Mattheson's Der vollkommene Capellmeister: a revised translation with critical commentary. UMI Research Press, $1981.920 \mathrm{p}$.

MATTHESON, Johann. Der vollkommene Capellmeister. New York: Ed. Kassel, 1999.

MED, Bohumil. Teoria da música. 4. ed. rev. e ampl. Brasília, DF: Musimed, 1996.

NO CEMITÉRIO, O Fluminense, 22 out. 1904, p. 1.

PÉREZ, Renard. Machado de Assis: esboço biográfico. In: Obra completa. Rio de Janeiro: Nova Aguiar, $1971,1^{\circ}$ vol.

Artigo em periódico

SCHAPOCHNIK, Nelson. Edição, recepção e mobilidade do romance Les mystères de Paris no Brasil oitocentista. Varia História. Belo Horizonte, vol. 26, n. 44, jul./dez. 2010, p. 591-617. 


\section{Textos em meio eletrônico}

CORREIO Mercantil, Notícias diversas, 24 nov. 1859, p. 1. Disponível em: http://memoria.bn.br/DocReader/docreader.aspx?bib=100439_04\&pasta=an o\%20190\&pesq=Carolina\%20Machado\%20de\%20Assis. Acesso em: $13 \mathrm{dez}$. 2015.

MARQUES, Carolina. Única herdeira do grande amor de Machado de Assis conta história do casal. Extra. Disponível em: http://extra.globo.com/tv-elazer/unica-herdeira-do-grande-amor-de-machado-de-assis-contahistorias-do-casal-582277.html. Acesso em: 15 jan. 2016.

\section{Teses e dissertações}

OLIVEIRA, Arnon Sávio Reis de. Hostílio Soares: As sete palavras de Christus Cruxificatum - Edição Crítica. 2001. 122 f. Dissertação (Mestrado em Música) - Centro de Letras e Artes, Universidade do Rio de Janeiro, Rio de Janeiro, 2001.

OLIVEIRA, Arnon Sávio Reis de. "O coro do Brasil" o madrigal renascentista e o contexto de seu percurso (1956-1962). Belo Horizonte, UFMG, 2015. 283p. Tese de doutorado, Faculdade de História da Universidade Federal de Minas Gerais.

TEIXEIRA, Márcia Maria Reis. As canções de Hostílio Soares: Álbum para canto e piano - cinco peças em vernáculo. Belo Horizonte, UFMG, 2010. 187p. Dissertação de mestrado, Escola de Música da Universidade Federal de Minas Gerais.

\section{Partitura}

SOARES, Hostílio. "A Carolina". Para canto e piano. Partitura. Belo Horizonte: manuscrito, s.d. Cópia de Afonso de Paula Silva. 


\section{A Carolina}
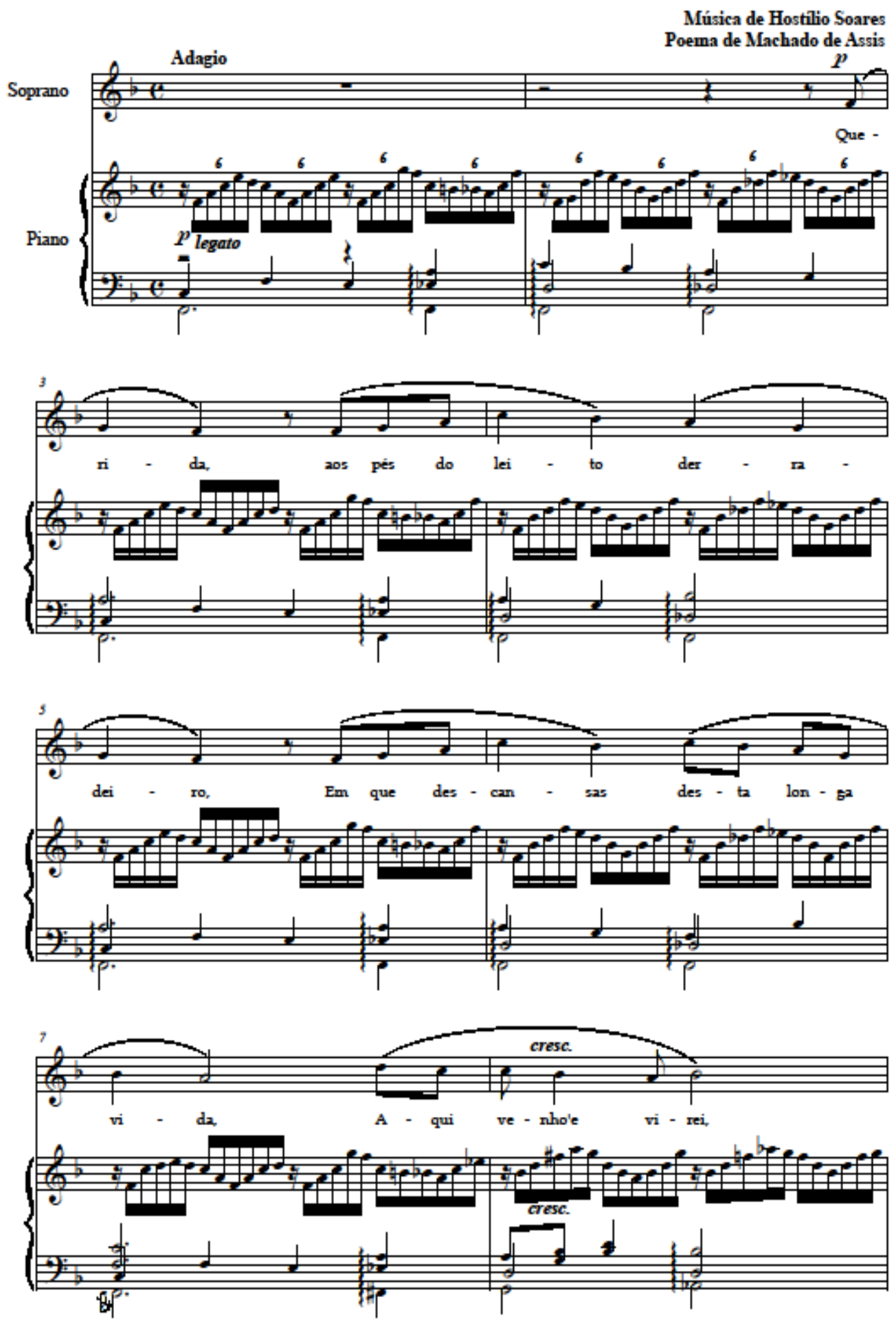

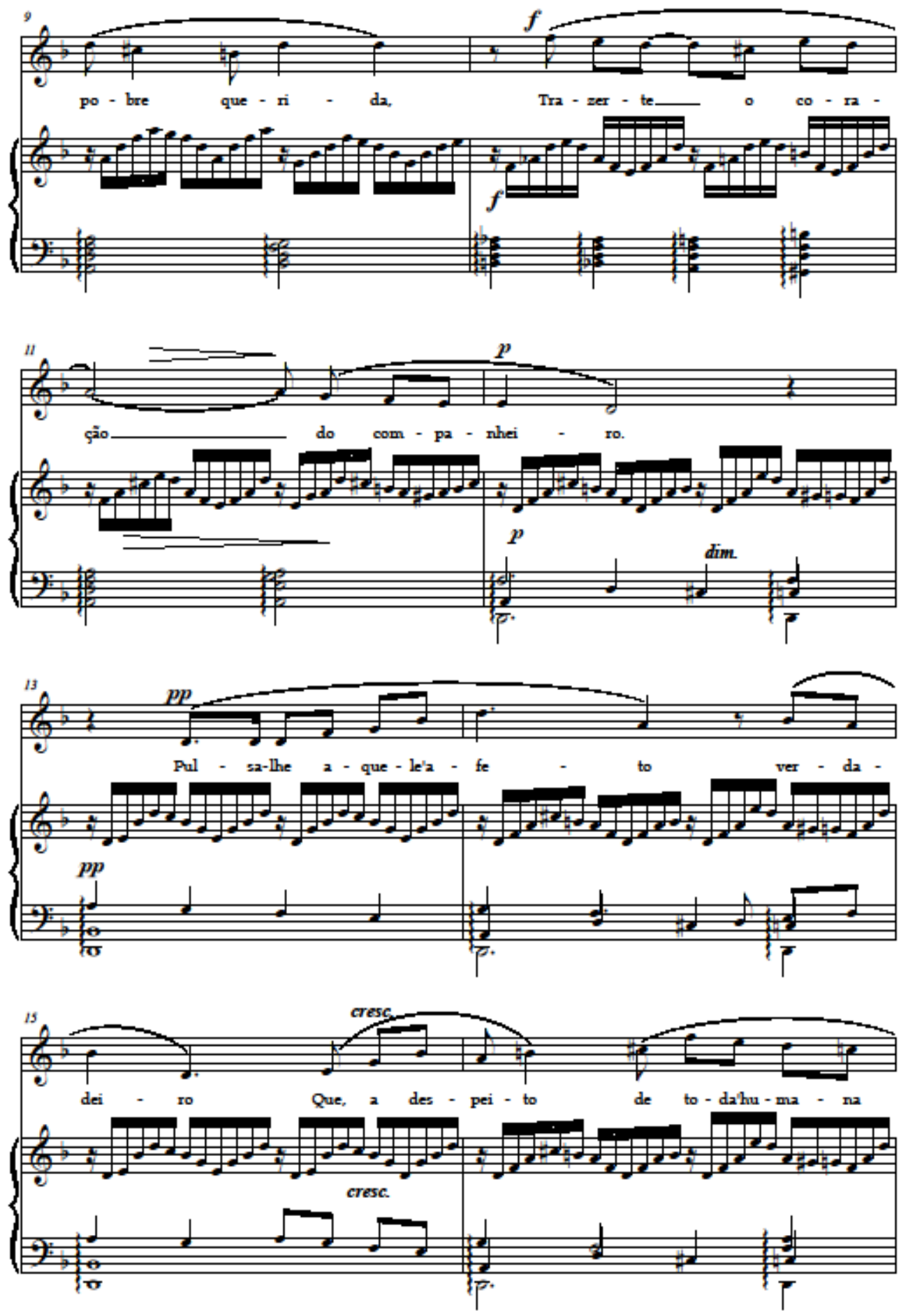

$-2-$ 

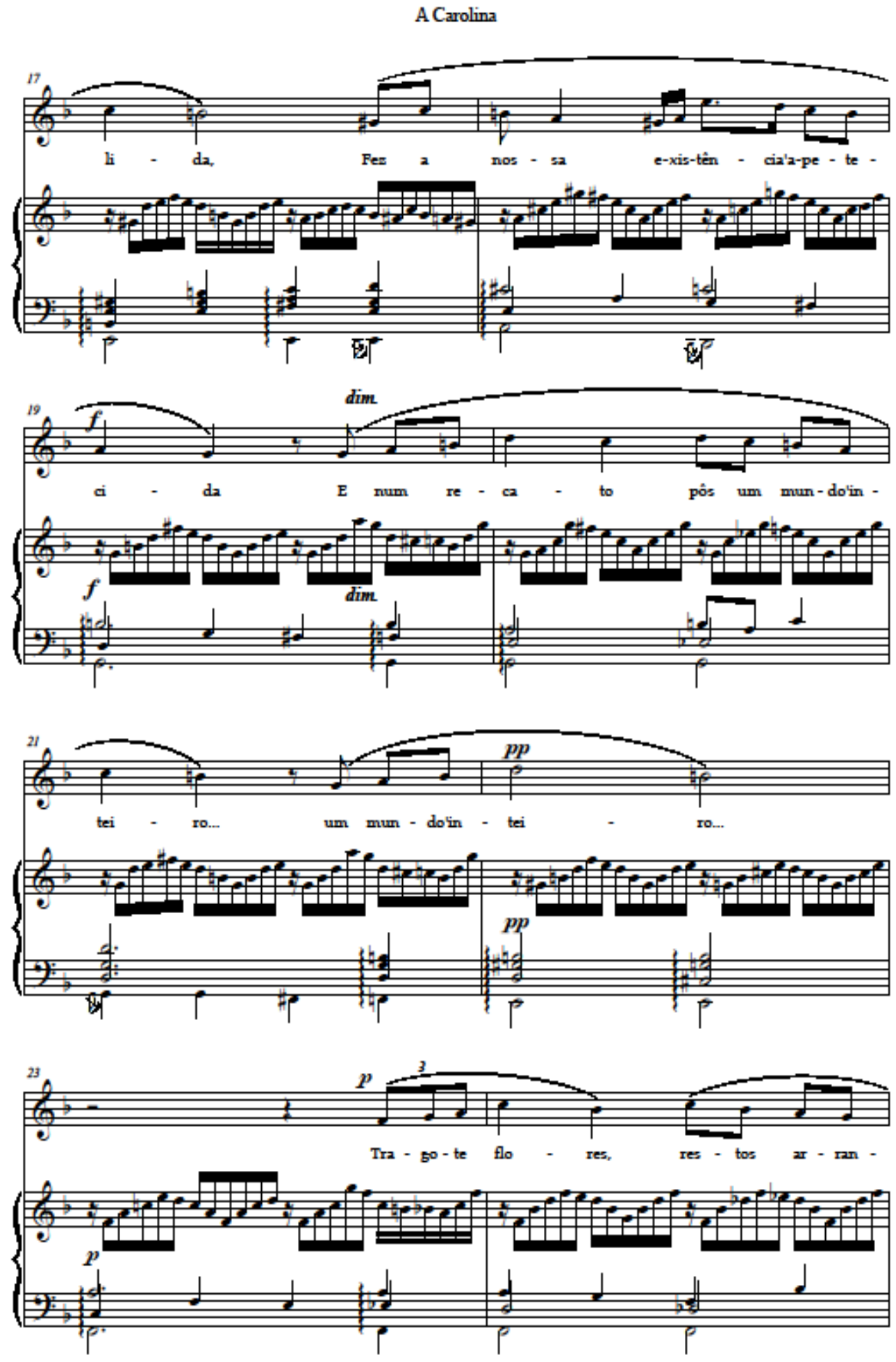

$-3-$ 

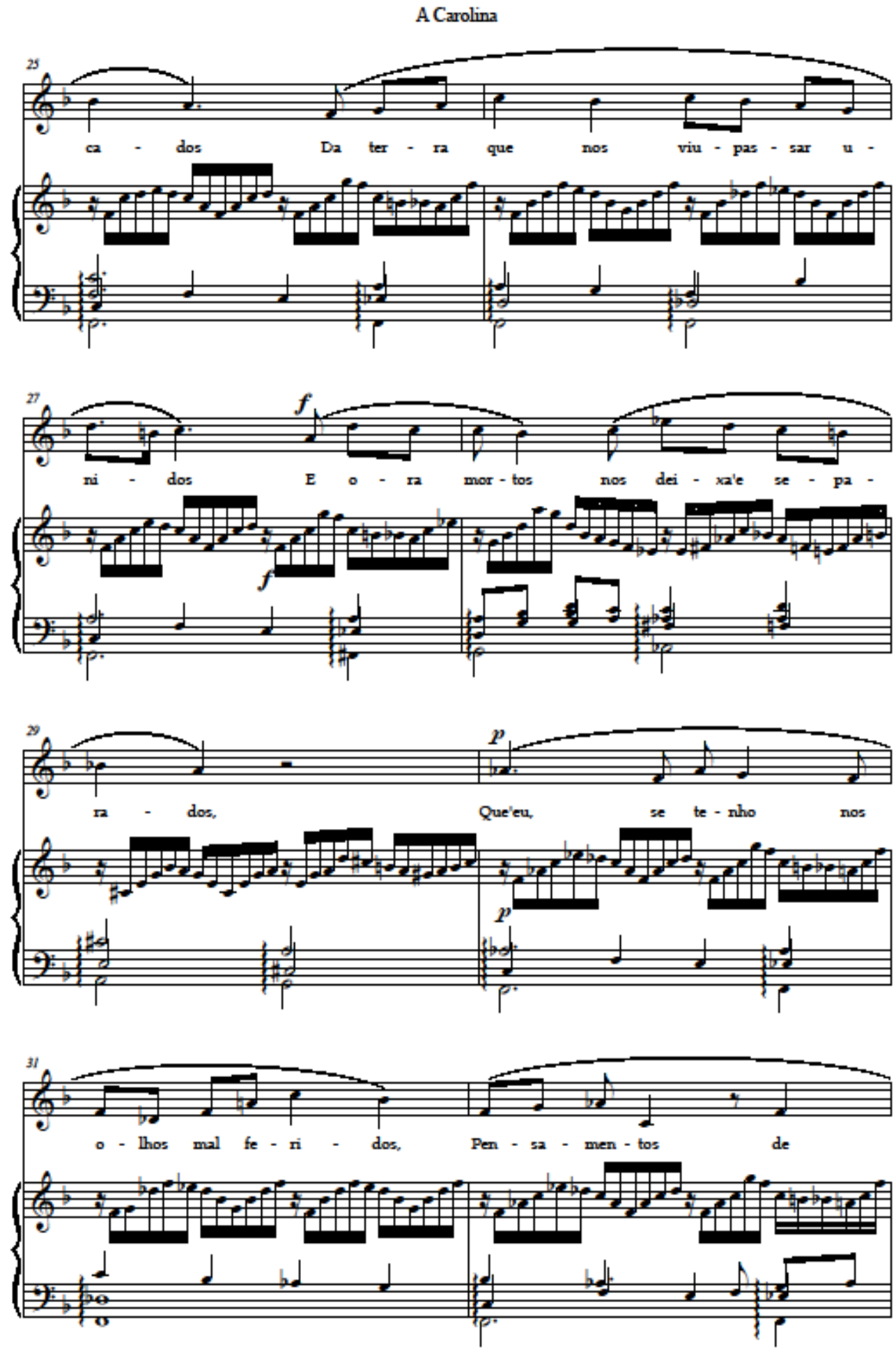

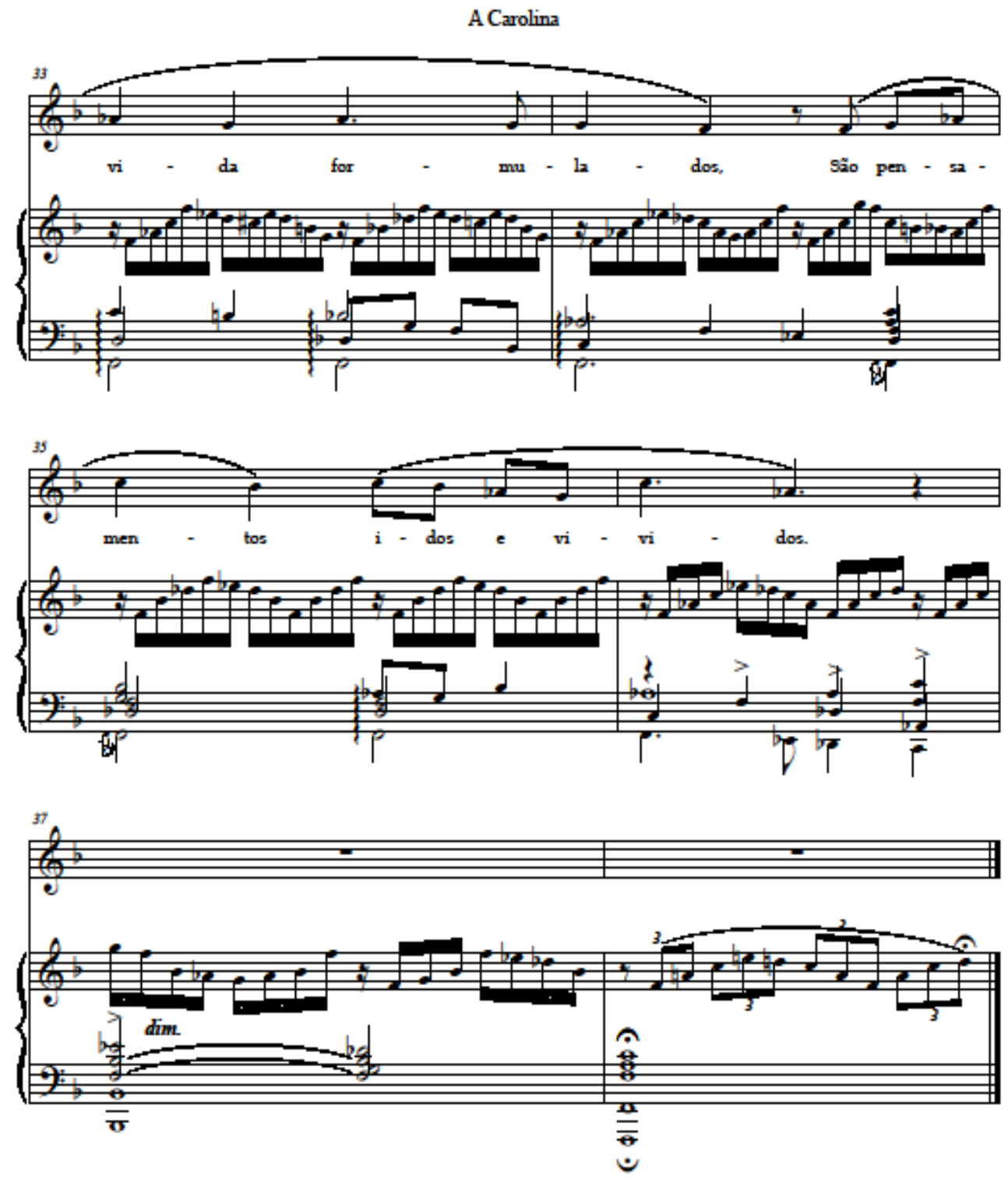
ARNON SÁVIO REIS DE OLIVEIRA é mestre em Musicologia pela Unirio e doutor em História pela UFMG. É docente na Escola de Música da UFMG, atuando na área de regência coral. Distingue-se pelo trabalho com coros e é autor de artigos sobre a obra de Hostílio Soares, tais como "Hostílio Soares: As sete palavras de Christus Cruxificatum", Revista Modus, Escola de Música da UEMG, 2002, ano II/2, p. 7-11; e "O catálogo de obras de Hostílio Soares", Revista Permusi, Escola de Música da UFMG, 2002, vol. 6, p. 167-175. E-mail: arnonsroliveira@gmail.com.

MAURO CAMILO DE CHANTAL SANTOS é doutor em música pela Unicamp, tendo pesquisado a vida e a obra do compositor Arthur lberê de Lemos, mais especificamente a ópera $A$ ceia dos cardeais. Pianista e cantor, atua na graduação e também na pósgraduação da Escola de Música da UFMG. Seus últimos trabalhos publicados são os artigos: com A. G. Kayama, "A ceia dos cardeais, ópera de Arthur Iberê de Lemos: sua criação e estreia", Revista Brasileira de Música (Rio de Janeiro. 1934), v. 28/1, 2015; com J. M. C. D. Lopes, "Os pianistas Judith Ribas e Cardoso de Menezes: Portugal e Brasil a quatro mãos", Brasil-Europa, vol. 2, p. 21, 2015; com M. M. R. Teixeira, "O álbum para canto e piano - cinco peças em vernáculo, de Hostílio Soares", Música Hodie, vol. 14, p. 138-155, 2014. E-mail: maurochantal@gmail.com.

PATRICIA VALADÃO ALMEIDA DE OLIVEIRA é professora assistente da Universidade Federal de Minas Gerais. Entre seus trabalhos mais recentes estão: Inovamus - Grupo de Pesquisa e Desenvolvimento de Tecnologias Aplicadas à Música, e a publicação do artigo "Evocação romântica Schumanniana, composição para piano de Carlos Alberto Pinto Fonseca: histórico, resgate e edição crítica" no III ENCONTRO NACIONAL DE PIANO: A Performance e Pedagogia do Piano na Contemporaneidade (Goiânia, 2015 p. 34-40). Email: valadao.patricia@gmail.com.

Recebido: 25.02 .16

Aprovado: 17.05 .16 